\title{
Digestible threonine to lysine ratio in diets for laying hens aged 24-40 weeks
}

\author{
Tatiana Cristina da Rocha ${ }^{1}$, Paulo Cezar Gomes ${ }^{1}$, Juarez Lopes Donzele ${ }^{1}$, Horacio Santiago \\ Rostagno ${ }^{1}$, Heloisa Helena de Carvalho Mello ${ }^{1}$, Cleverson Luís Nascimento Ribeiro', \\ Allan Reis Troni ${ }^{1}$
}

\begin{abstract}
${ }^{1}$ Departamento de Zootecnia, Universidade Federal de Viçosa, Viçosa, MG, Brasil.
ABSTRACT - Two-hundred sixteen white laying hens were used to assess the ideal ratio of digestible threonine:lysine in diets for laying hens at 24 to 40 weeks of age. Birds were assigned to a randomized block design, with six treatments, six replicates per treatment and six birds per experimental unit. The cage was used as the blocking criterion. Experimental diets contained different digestible threonine:digestible lysine ratios $(65,70,75,80,85$ and 90\%) with $142 \mathrm{~g} / \mathrm{kg}$ of crude protein. Experimental diets were formulated to be isonitrogenous and isocaloric with different contents of L-glutamic acid. Feed intake $(\mathrm{g} / \mathrm{hen} / \mathrm{d})$, egg production (\%), egg weight $(\mathrm{g})$, egg mass ( $\mathrm{g} / \mathrm{hen} / \mathrm{d})$, feed conversion ratio ( $\mathrm{kg} / \mathrm{dozen}$ and $\mathrm{kg} / \mathrm{kg}$ egg), eggshell weight $(\mathrm{g})$, albumen weight $(\mathrm{g})$, yolk weight $(\mathrm{g})$ and body weight gain $(\mathrm{g})$ were assessed. The maximum egg production was observed at $78 \%$ digestible threonine:digestible lysine ratio, while the best values of feed conversion ratio ( $\mathrm{kg} / \mathrm{dozen}$ egg) and feed conversion ratio $(\mathrm{kg} / \mathrm{kg}$ of egg) were observed at $77.6 \%$ and $75 \%$, respectively. Feed intake, egg mass and egg contents (yolk, albumen and eggshell) were not affected by treatments. The estimated digestible threonine:digestible lysine ratio of Hy-Line W36 laying hens at 24 to 40 weeks of age is $78 \%$, corresponding to $5.70 \mathrm{~g} / \mathrm{kg}$ of dietary digestible threonine.
\end{abstract}

Key Words: amino acids, egg production, ideal protein, white laying hens

\section{Introduction}

The Brazilian egg production has increased in the past few years. According to UBABEF (2013), the Brazilian egg production in 2012 was approximately 31 billion units and per capita consumption of 161.53 units/year.

The increase in egg production has been possible due the studies of the daily requirement of indispensable amino acids for laying hens. This knowledge allows for maximizing egg production, decreasing environmental impacts by reduction of nitrogen excretion and consequently reducing production costs.

In this context, formulation of diets based on the concept of ideal protein is very important, as the nitrogen excretion is reduced when laying hens are fed a profile of amino acids closer to their nutritional requirements. However, formulation of diets based on the crude protein concept may lead to a situation of a lack or excess of certain amino acids. As a result, the feed intake and productive performance of laying hens may be compromised. For laying hens in production phase, the adequacy of dietary amino acids is very important due to their requirements of protein for egg production.

Threonine is third limiting amino acid in corn- and soybean meal-based diets for laying hens. Threonine is related to metabolic processes like acid uric formation and protein synthesis. It has been verified that threonine might function as a nutrient immunomodulator in maintaining the intestinal barrier function (Azzam et al., 2011).

Because laying hens have low protein synthesis requirement and the threonine requirement is a large component of maintenance, a minimum threonine:lysine ratio may need to be met in formulating diets for laying hens (Martínez-Amescua et al., 1999). Studies have demonstrated that reducing dietary level of crude protein and using L-threonine supplementation has no negative effect on quantitative laying production (Gheisar et al., 2011).

Therefore, this study was conducted to determine the ideal ratio of digestible threonine to lysine in diets for Hy-Line W36 laying hens at 24 to 40 weeks of age.

\section{Material and Methods}

Two hundred sixteen Hy-Line W-36 laying hens from 24 to 40 weeks of age were assigned to a randomized block design with six treatments, six replicates and six hens per experimental unit. The cage was used as the blocking criterion. Laying hens were handled from 20 weeks old until the beginning of the trial, at 24 weeks old, following recommendations of the Hy-Line W36 Commercial Management Guide and fed according to Rostagno et al. (2005). 
The laying hens were confined in compact-type wire cages $(25 \times 45 \mathrm{~cm})$ in a bi-level system. Nipple drinkers were provided in each cage and hens had free access to water. Feeders were provided for each cage with a capacity of two hens per cage. Hens were fed the experimental diets from 24 to 40 weeks of age. Experimental diets were offered for 16 weeks, divided into four periods of four weeks.

Before the experimental diets were provided, laying hens were individually weighed and randomly allotted to pens so that all pens had approximately the same average body weight $(1,328 \mathrm{~g})$ and egg production. The control of egg production was carried out in the period between 20 and 24 weeks of age. At 24 weeks of age, the laying hens received the experimental diets. Hens were given free access to water and experimental diets.

The treatments consisted of six levels of digestible threonine $(4.75,5.11,5.48,5.84,6.21$ and $6.57 \mathrm{~g} / \mathrm{kg}$ ), resulting in different digestible threonine:digestible lysine ratios, as follows: $65,70,75,80,85$ and $90 \%$. A basal diet was formulated with $4.75 \mathrm{~g} / \mathrm{kg}$ of digestible threonine (Table 1). Experimental diets were prepared from the basal diet by varying the levels of L-threonine, which was added to the basal diet in substitution of cornstarch and the nonessential amino acid L-glutamic acid.

All diets were isonitrogenous and had the same ratio of essential amino acids in relation to lysine, except threonine, and 100, 25, 85, 92, 102, 124, 31, 67 and 120\% to digestible methionine+cystine; digestible tryptophan; digestible isoleucine; digestible valine, digestible arginine, digestible leucine, digestible histidine, digestible phenylalanine and digestible phenylalanine + tyrosine, respectively. The digestible methionine + cystine:digestible lysine ratio was used as recommended by Brumano et al. (2010) and the digestible lysine:digestible other-aminoacids ratio was used according to the recommendations of Rostagno et al. (2005).

At the onset of production, the exposure of the animals to light was gradually increased by increments of $15 \mathrm{~min}$ per week to reach a constant photoperiod of 16 hours of light and 8 hours of darkness (16L:8D). Laying hens received additional artificial light provided by incandescent lighting.

The lowest and highest temperatures recorded were 19.4 and $28.2{ }^{\circ} \mathrm{C}$, respectively. According to the Hy-Line W36 Commercial Management Guide (Hy-Line of Brazil, 2009-2011), the temperature inside the laying house should be 18 to $27^{\circ} \mathrm{C}$. Therefore, it can be inferred that the hens were exposed to thermal stress during the experimental period.
The effects of dietary treatment on egg production (\%), feed intake $(\mathrm{g} / \mathrm{hen} / \mathrm{d})$, feed conversion ratio $(\mathrm{kg} /$ dozen and $\mathrm{kg} / \mathrm{kg}$ of egg), egg weight ( $\mathrm{g}$ ), egg mass ( $\mathrm{g} / \mathrm{hen} / \mathrm{d}$ ), eggshell weight (g), albumen weight ( $\mathrm{g}$ ), yolk weight $(\mathrm{g})$ and mortality were evaluated. Individual body weight (g) was recorded at the beginning and end of the experiment.

Analysis of variance was performed by using the statistical analysis system SAEG (Sistemas para Análises Estatísticas, version 9.1). The digestible threonine:digestible lysine ratio was determined by the polynomial regression. Statistical significance was considered at $\mathrm{P}<0.05$.

Table 1 - Composition of basal diet

\begin{tabular}{|c|c|}
\hline Ingredient & $\mathrm{g} / \mathrm{kg}$ \\
\hline Corn & 651.97 \\
\hline Soybean meal & 138.36 \\
\hline Corn gluten meal $60 \%$ & 16.37 \\
\hline Sorghum & 50.00 \\
\hline Dicalcium phosphate & 15.73 \\
\hline Limestone & 93.23 \\
\hline Salt & 5.09 \\
\hline Vegetable oil & 9.70 \\
\hline L-lysine $\mathrm{HCl}$ & 2.75 \\
\hline DL-methionine & 3.55 \\
\hline L-arginine & 0.44 \\
\hline L-valine & 1.37 \\
\hline L-isoleucine & 1.60 \\
\hline L-tryptophan & 0.82 \\
\hline$V$ itamin premix $^{1}$ & 1.00 \\
\hline Mineral premix ${ }^{2}$ & 0.50 \\
\hline Potassium carbonate & 2.23 \\
\hline Choline & 0.20 \\
\hline Antioxidant $^{3}$ & 0.10 \\
\hline L-glutamic acid & 4.47 \\
\hline L-threonine & 0.38 \\
\hline Cornstarch & 0.13 \\
\hline \multicolumn{2}{|l|}{ Calculated composition (g/kg) } \\
\hline Metabolizable energy (kcal/kg) & 2900 \\
\hline Crude protein $(\mathrm{g} / \mathrm{kg})$ & 142.00 \\
\hline Linoleic acid $(\mathrm{g} / \mathrm{kg})$ & 12.10 \\
\hline Digestible lysine $(\mathrm{g} / \mathrm{kg})$ & 7.30 \\
\hline Digestible methionine + cystine $(\mathrm{g} / \mathrm{kg})$ & 7.67 \\
\hline Digestible methionine $(\mathrm{g} / \mathrm{kg})$ & 4.02 \\
\hline Digestible tryptophan $(\mathrm{g} / \mathrm{kg})$ & 2.04 \\
\hline Digestible threonine $(\mathrm{g} / \mathrm{kg})$ & 4.75 \\
\hline Digestible valine $(\mathrm{g} / \mathrm{kg})$ & 6.94 \\
\hline Digestible histidine $(\mathrm{g} / \mathrm{kg})$ & 3.39 \\
\hline Digestible isoleucine $(\mathrm{g} / \mathrm{kg})$ & 6.42 \\
\hline Digestible arginine $(\mathrm{g} / \mathrm{kg})$ & 7.67 \\
\hline Digestible leucine $(\mathrm{g} / \mathrm{kg})$ & 13.00 \\
\hline Digestible phenylalanine $(\mathrm{g} / \mathrm{kg})$ & 6.21 \\
\hline Digestible phenylalanine + tyrosine & 10.60 \\
\hline Calcium $(\mathrm{g} / \mathrm{kg})$ & 40.20 \\
\hline Available phosphorus (g/kg) & 3.75 \\
\hline Sodium $(\mathrm{g} / \mathrm{kg})$ & 2.25 \\
\hline Chlorine $(\mathrm{g} / \mathrm{kg})$ & 2.00 \\
\hline Potassium (g/kg) & 5.80 \\
\hline \multicolumn{2}{|c|}{$\begin{array}{l}{ }^{1} \text { Content per kg premix: vitamin A - 12,000,000 IU; vitamin D3 - 3,600,000 IU; } \\
\text { vitamin E - 3,500 IU; vitamin B1 - 2,500 mg; vitamin B2-8,000 mg; vitamin B6-3,000 mg; } \\
\text { pantothenic acid - 12,000 mg; biotin - } 200 \mathrm{mg} \text {; vitamin K - 3,000 mg; folacin - } \\
3,500 \mathrm{mg} \text {; niacin - 40,000 mg; vitamin B - 1,220,000 mcg; Se - } 130 \mathrm{mg} \text {. } \\
2 \text { Content per kg premix: Mn - } 160 \mathrm{~g} ; \mathrm{Fe}-100 \mathrm{~g} ; \mathrm{Zn}-100 \mathrm{~g} \text {; Cu - } 20 \mathrm{~g} \text {; Co - } 2 \mathrm{~g} \text {; } \\
\text { I - } 2 \text { g. } \\
{ }^{3} \text { BHT - Butylated Hydroxytoluene. }\end{array}$} \\
\hline
\end{tabular}




\section{Results and Discussion}

Digestible threonine:digestible lysine ratios had no effect on feed intake by laying hens (Table 2). This result is consistent with the idea that laying hens may be unable to compensate threonine deficiency by increasing feed intake described by Martínez-Amescua et al. (1999). In addition, Valério et al. (2000) found no differences in the feed intake of hens from 21 to $36 \mathrm{wk}$ of age that were fed diets with different levels of digestible threonine and $142 \mathrm{~g} / \mathrm{kg}$ of crude protein.

Digestible threonine intake increased linearly with increasing dietary threonine levels $(\mathrm{P}<0.01)$ (Table 2). Because feed intake did not differ among treatments, as digestible threonine increased, threonine intake increased linearly. This fact enables the observation of the effects of threonine on laying hens performance. Regression analysis for egg weight resulted in a linear response since the egg weight decreased as the digestible threonine content of the diet increased $\left(\hat{Y}=61.08-8.88 x, R^{2}=0.80\right)$ (Table 2). The average egg weight observed in the present study was lower than those presented by the Guidelines for the breed (58.08 g).

In contrast, Martinez-Amescua et al. (1999) observed increase in egg weight when the dietary threonine (threonine:lysine ratio of 62\%) increased from $4.3 \mathrm{~g} / \mathrm{kg}$ to $4.7 \mathrm{~g} / \mathrm{kg}$ (threonine:lysine ratio of $68 \%$ ). Similarly, Faria et al. (2002) verified that egg weight increased as the threonine content of the diet increased. Additionally, Ishibashi et al. (1998), Valério et al. (2000) and Gomez \& Angeles (2009) reported a lack of differences in egg weight due to increasing dietary levels of threonine. According to the last authors, these discrepancies may be due to the basal diets used in these studies.

Egg production increased quadratically, being highest at the $5.70 \mathrm{~g} / \mathrm{kg}$ digestible threonine, corresponding to a digestible threonine:digestible lysine ratio of $78 \%$ $\left(\hat{Y}=-57.88+498.7 x-436.91 x^{2}, R^{2}=0.50\right)($ Table 2$)$.

The effect of threonine on egg production is well established and depends on the breed and age of the layer. Matos et al. (2009) reported that egg production is maximum at a digestible threonine:lysine ratio of $69 \%$ for Lohmann LSL laying hens at 24 to 44 weeks of age. Gomez \& Angeles (2009) reported a threonine:lysine ratio of $65 \%$ for maximum egg production by Hy-Line W-36 laying hens at 100 weeks of age.

Feed conversion ratio $(\mathrm{kg} /$ dozen) showed a quadratic pattern $(\mathrm{P}<0.01)$, being greater with a dietary digestible threonine concentration of $5.67 \mathrm{~g} / \mathrm{kg}$, which was equivalent to a digestible threonine:digestible lysine ratio of $77.6 \%$ $\left(\hat{Y}=3.481-7.648 x+6.74 x^{2}, R^{2}=0.90\right)($ Table 3$)$. This result corroborates the findings of Sá et al. (2007) and Matos et al. (2009), who found that dietary threonine influences the feed conversion ratio. Similarly, the quadratic regression of feed conversion ratio $(\mathrm{kg} / \mathrm{kg})$ indicated a requirement of $5.47 \mathrm{~g} / \mathrm{kg}$ digestible threonine, corresponding to a digestible threonine:digestible lysine ratio of $75 \%(\hat{Y}=4.277-8.497 \mathrm{x}$ $\left.+7.76 \mathrm{x}^{2}, \mathrm{R}^{2}=0.81\right)$. As such, the best digestible threonine: digestible lysine ratio to ensure optimal feed conversion ratio $(77.6 \%)$ coincides with the best digestible threonine: digestible lysine ratio for maximum egg production (78\%). Moreover, a digestible threonine:digestible lysine ratio higher than $75 \%$ resulted in decrease in egg weight. Egg mass was not affected by digestible threonine:digestible lysine ratio (Table 3). In contrast, Bregendahl et al. (2008) verified that the digestible threonine:digestible lysine ratio affected the egg mass of Hy-Line W-36 laying hens at 26 to 34 weeks of age, which was maximized at a threonine intake of $414 \mathrm{mg} / \mathrm{hen} / \mathrm{d}$, corresponding to $77 \%$ relative to lysine.

According to Sakomura \& Rostagno (2007), $8.7 \mathrm{mg}$ of digestible threonine is required for each gram of egg

Table 2 - Feed intake, digestible threonine intake, egg weight and egg production according to digestible threonine:digestible lysine ratio

\begin{tabular}{|c|c|c|c|c|c|}
\hline $\begin{array}{l}\text { Digestible threonine: } \\
\text { digestible lysine ratio }\end{array}$ & $\begin{array}{l}\text { Digestible threonine } \\
\text { intake }(\mathrm{g} / \mathrm{kg})\end{array}$ & Feed intake $(\mathrm{g} / \mathrm{hen} / \mathrm{d})$ & $\begin{array}{l}\text { Threonine intake } \\
\text { (g/hen/d) }\end{array}$ & Egg weight (g/egg) & Egg production (\%) \\
\hline 65 & 4.75 & 91.22 & 0.433 & 57.15 & 79.1 \\
\hline 70 & 5.11 & 93.74 & 0.479 & 56.58 & 84.6 \\
\hline 80 & 5.84 & 89.57 & 0.523 & 55.44 & 82.2 \\
\hline 85 & 6.21 & 93.32 & 0.579 & 55.58 & 84.5 \\
\hline 90 & 6.57 & 89.80 & 0.590 & 55.67 & 81.8 \\
\hline Linear effect & & 0.286 & 0.000 & 0.011 & 0.651 \\
\hline Quadratic effect & & 0.290 & 0.270 & 0.263 & 0.012 \\
\hline Lack of fit & & 0.123 & 0.112 & 0.657 & 0.127 \\
\hline CV $(\%)$ & & 3.51 & 3.53 & 2.12 & 3.70 \\
\hline
\end{tabular}


produced. Considering that the average egg mass in the present study was $46.34 \mathrm{~g} / \mathrm{hen} / \mathrm{d}$ and that the lowest digestible threonine:digestible lysine ratio was sufficient to ensure this, $9.34 \mathrm{mg}$ of digestible threonine was required for each gram of egg produced.

The average weight of yolk, albumen, eggshell and egg content in percentage in the hens receiving diets with 65 to $90 \%$ digestible threonine:digestible lysine ratio were not different (Tables 4 and 5). Therefore, it can be concluded that, for the levels of digestible threonine evaluated in this study, no major effects were observed on egg quality. Laying hens gained weight during the experimental period (Table 6). Koelkebeck et al. (1991) suggested that an excess of $1 \%$ of threonine seemed to have minimal effects on feed intake and weight gain in laying hens. Faria et al. (2002) verified a decrease in body weights of hens fed diets containing less than $4.5 \mathrm{~g} / \mathrm{kg}$ threonine, which is lower than the levels evaluated in this study. The optimum ratios of digestible threonine:digestible lysine (Table 7 ) ranged from $75 \%$ to $90 \%$. Considering that feed conversion ratio is an important production parameter, and an $\mathrm{R}^{2}$ for regression equation of 0.90 , the optimum digestible threonine:digestible

Table 3 - Feed conversion ratio and egg mass according to treatments digestible threonine:digestible lysine ratio

\begin{tabular}{|c|c|c|c|c|}
\hline $\begin{array}{l}\text { Digestible threonine: } \\
\text { digestible lysine ratio }\end{array}$ & Digestible threonine $(\mathrm{g} / \mathrm{kg})$ & $\begin{array}{c}\text { Feed conversion ratio } \\
(\mathrm{kg} / \text { dozen })\end{array}$ & $\begin{array}{c}\text { Feed conversion ratio } \\
(\mathrm{kg} / \mathrm{kg} \text { egg })\end{array}$ & $\begin{array}{l}\text { Egg mass } \\
(\mathrm{g} / \mathrm{hen} / \mathrm{d})\end{array}$ \\
\hline 65 & 4.75 & 1.37 & 2.00 & 45.59 \\
\hline 70 & 5.11 & 1.32 & 1.94 & 48.21 \\
\hline 75 & 5.48 & 1.31 & 1.93 & 48.06 \\
\hline 80 & 5.84 & 1.32 & 1.98 & 45.22 \\
\hline 85 & 6.21 & 1.34 & 2.00 & 46.58 \\
\hline \multirow[t]{2}{*}{90} & 6.57 & 1.35 & 2.01 & 44.42 \\
\hline & & & P-value & \\
\hline Linear effect & & 0.876 & 0.176 & 0.076 \\
\hline Quadratic effect & & 0.006 & 0.058 & 0.360 \\
\hline Lack of fit & & 0.589 & 0.510 & 0.133 \\
\hline $\mathrm{CV}(\%)$ & & 3.33 & 3.90 & 4.63 \\
\hline
\end{tabular}

Table 4 - Yolk weight, albumen weight and eggshell weight according to digestible threonine:digestible lysine ratio

\begin{tabular}{|c|c|c|c|c|}
\hline $\begin{array}{l}\text { Digestible threonine: } \\
\text { digestible lysine ratio }\end{array}$ & Digestible threonine $(\mathrm{g} / \mathrm{kg})$ & Yolk weight (g) & Albumen weight (g) & Eggshell weight (g) \\
\hline 65 & 4.75 & 14.79 & 37.04 & 5.00 \\
\hline 70 & 5.11 & 14.80 & 37.30 & 4.78 \\
\hline 80 & 5.84 & 14.72 & 36.26 & 4.90 \\
\hline 85 & 6.21 & 14.63 & 36.81 & 4.86 \\
\hline 90 & 6.57 & 14.66 & 36.96 & 4.99 \\
\hline Linear effect & & 0.258 & 0.477 & 0.805 \\
\hline Quadratic effect & & 0.628 & 0.621 & 0.217 \\
\hline Lack of fit & & 0.599 & 1.225 & 0.387 \\
\hline CV (\%) & & 2.29 & 3.11 & 5.06 \\
\hline
\end{tabular}

Table 5 - Yolk, albumen and eggshell contents according to digestible threonine:digestible lysine ratio

\begin{tabular}{lcccc}
\hline $\begin{array}{l}\text { Digestible threonine: } \\
\text { digestible lysine ratio }\end{array}$ & Digestible threonine $(\mathrm{g} / \mathrm{kg})$ & Yolk $(\mathrm{g} / 100 \mathrm{~g}$ of egg) & Albumen $(\mathrm{g} / 100 \mathrm{~g}$ of egg) & Eggshell $(\mathrm{g} / 100 \mathrm{~g}$ of egg) \\
\hline 65 & 4.75 & 26.00 & 65.20 & 85.61 \\
70 & 5.11 & 26.02 & 65.28 & 8.80 \\
75 & 5.48 & 26.14 & 64.94 & 8.58 \\
80 & 5.84 & 26.30 & 65.39 & 8.76 \\
85 & 6.21 & 25.96 & 65.31 & 8.65 \\
90 & 6.57 & 25.87 & & P-value \\
& & & 0.847 & 0.791 \\
Linear effect & & 0.738 & 0.344 & 0.391 \\
Quadratic effect & & 0.272 & 0.399 \\
Lack of fit & & 2.629 & 1.09 & 5.61 \\
CV (\%) & & & \\
\hline
\end{tabular}


Table 6 - Initial body weight, final body weight and change in body weight according to digestible threonine:digestible lysine ratio

\begin{tabular}{|c|c|c|c|c|}
\hline $\begin{array}{l}\text { Digestible threonine: } \\
\text { digestible lysine ratio }\end{array}$ & Digestible threonine $(\mathrm{g} / \mathrm{kg})$ & Initial body weight (g) & Final body weight (g) & Body weight change (g) \\
\hline 65 & 4.75 & 1329.2 & 1438.9 & 109.7 \\
\hline 70 & 5.11 & 1324.4 & 1444.3 & 119.9 \\
\hline 80 & 5.84 & 1327.4 & 1433.9 & 106.5 \\
\hline 85 & 6.21 & 1328.7 & 1465.4 & 136.7 \\
\hline 90 & 6.57 & 1330.5 & 1416.5 & 86.0 \\
\hline Linear & & 0.407 & 0.768 & 0.710 \\
\hline Quadratic & & 0.489 & 0.517 & 0.483 \\
\hline Lack of fit & & 0.125 & 0.137 & 0.144 \\
\hline $\mathrm{CV}(\%)$ & & 0.44 & 3.98 & 52.4 \\
\hline
\end{tabular}

Table 7 - Digestible threonine:digestible lysine ratios according to the parameter evaluated

\begin{tabular}{lccc}
\hline & $\begin{array}{c}\text { Digestible threonine:digestible } \\
\text { lysine ratio }\end{array}$ & Equation & $\mathrm{R}^{2}$ \\
\hline Egg weight & $>90 \%$ & $\hat{\mathrm{Y}}=61.08-8.88 \mathrm{x}$ & \\
Egg production & $78 \%$ & $\hat{\mathrm{Y}}=57.88+498.7 \mathrm{x}-436.91 \mathrm{x}^{2}$ & 0.80 \\
Feed conversion ratio (kg/dozen) & $77.6 \%$ & $\hat{\mathrm{Y}}=3.481-7.648 \mathrm{x}+6.74 \mathrm{x}^{2}$ & 0.50 \\
Feed conversion ratio (kg/kg of $\mathrm{egg})$ & $75 \%$ & $\hat{\mathrm{Y}}=4.277-8.497 \mathrm{x}+7.76 \mathrm{x}^{2}$ & 0.90 \\
\hline
\end{tabular}

lysine ratio of $77.6 \%$ for Hy-Line W-36 laying hens aged 24-40 weeks is recommended. In summary, the digestible threonine:digestible lysine ratio influences egg production, egg weight and feed conversion ratio, but does not affect the egg quality. The digestible threonine:digestible lysine ratio was estimated to be $77.6 \%$. The digestible threonine: digestible lysine ratio determined in this study was higher than the $76 \%$ suggested by Rostagno et al. (2011).

\section{Conclusions}

For adequate productive performance of Hy-Line W36 laying hens at 24 to 40 weeks of age, the estimated digestible threonine:digestible lysine ratio is $77.6 \%$.

\section{Acknowledgments}

The authors thank Universidade Federal de Viçosa, CNPq (Conselho Nacional de Desenvolvimento Científico e Tecnológico) and Ajinomoto.

\section{References}

AZZAM, M.M.M.; ZOU, X.T.; DONG, X.Y. et al. Effect of supplemental L-threonine on mucin 2 gene expression and intestine mucosal immune and digestive enzymes activities of laying hens in environments with high temperature and humidity. Poultry Science, v.90, p.2251-2256, 2011.

BREGENDAHL, K.; ROBERTS, S.A.; KERR, B. et al. Ideal ratios of isoleucine, methionine, methionine plus cystine, threonine, tryptophan, and valine relative to lysine for white leghorn-type laying hens of twenty-eight to thirty-four weeks of age. Poultry Science, v.87, p.744-758, 2008

BRUMANO, G.; GOMES, P.C.; DONZELE, J.L. et al. Níveis de metionina + cistina digestível em rações para poedeiras leves no período de 24 a 40 semanas de idade. Revista Brasileira de Zootecnia, v.39, p.1228-1236, 2010.

FARIA, D.E.; HARMS, R.H.; RUSSELL, G.B. Threonine requirement of commercial laying hens fed a corn-soybean meal diet. Poultry Science, v.81, p.809-814, 2002.

GHEISAR,M.M.; FOROUDI, F.; GHAZIKHANI, A. Effect of using L-threonine and reducing dietary levels of crude protein on egg production in layers. Iranian Journal of Applied Animal Science, v.1, p.65-68, 2011.

GOMEZ, S.; ANGELES, M. Effect of threonine and methionine levels in the diet of laying hens in the second cycle of production. Journal Applied Poultry Research, v.18, p.452-457, 2009.

HY-LINE W36 COMMERCIAL MANAGEMENT GUIDE. [20092011]. Available at: <http://www.hylinedobrasil.com.br/website/ production/htms_pt/page_3.asp> Accessed on: Dec. 21, 2007.

ISHIBASHI, T.; OGAWA, Y.; ITOH, T. et al. Threonine requirements of laying hens. Poultry Science, v.77, p.998-1002, 1998.

KOELKEBECK, K.W.; BAKER, D.H.; HAN, Y. et al. Effect of excess lysine, methionine, threonine, or tryptophan on production performance of laying hens. Poultry Science, v.70, p.1651-1165, 1991.

MARTINEZ-AMEZCUA，C.; LAPARRA-VEJA，J.L.; AVILAGONZALES, E. et al. Dietary L-threonine responses in laying hens. Journal Applied Poultry Research, v.8, p.236-241, 1999.

MATOS, M.S.; LEANDRO, N.S.M.; STRINGHINI, J.H. et al. Níveis de lisina e treonina para poedeiras comerciais Lohmann LSL de 24 a 44 semanas de idade. Acta Scientiarum Animal Science, v.31, p.19-24, 2009.

ROSTAGNO, H.S.; ALBINO, L.F.T.; DONZELE, J.L. et al. Tabelas brasileiras para aves e suínos: composição de alimentos e exigências nutricionais. 2.ed. Viçosa, MG: UFV, Departamento de Zootecnia, 2005. 186p.

ROSTAGNO, H.S.; ALBINO, L.F.T.; DONZELE, J.L. et al. Tabelas brasileiras para aves e suínos: composição de alimentos e 
exigências nutricionais. 3.ed. Viçosa, MG: UFV, Departamento de Zootecnia, 2011. 252p.

SÁ, L.M.; GOMES. P.C.; CECON, P.R. et al. Exigência nutricional de threonine digestible para galinhas poedeiras no período de 34 a 50 semanas de idade. Revista Brasileira de Zootecnia, v.36, p.1846-1853, 2007.

SAKOMURA, N.K.; ROSTAGNO, H.S. Métodos de pesquisa em nutrição de monogástricos. Jaboticabal: FUNEP, 2007. 283p.
UBABEF União Brasileira de Avicultura. Relatório anual de 2013. Available at: $<$ http://www.ubabef.com.br/files/publicacoes/ 732e67e684103de4a2117dda9ddd280a.pdf >Accessed on: June 20, 2013.

VALERIO, S.R.; SOARES, P.R.; ROSTAGNO, H.S. et al. Determinação da exigência de treonina para poedeiras leves e semipesadas. Revista Brasileira de Zootecnia, v.29, p.518-524, 2000 . 